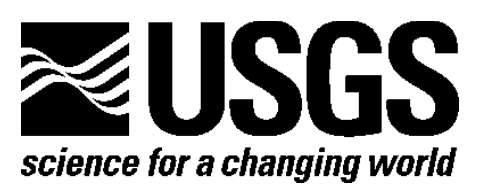

\title{
Water-Level Measurements in Dauphin Island, Alabama, From the 2013 Hurricane Season
}

By Patrick J. Dickhudt, Christopher R. Sherwood, and Nancy T. Dewitt

Open-File Report 2014-1245

U.S. Department of the Interior

U.S. Geological Survey 


\section{U.S. Department of the Interior SALLY JEWELL, Secretary}

\section{U.S. Geological Survey \\ Suzette M. Kimball, Acting Director}

U.S. Geological Survey, Reston, Virginia: 2015

For more information on the USGS—-the Federal source for science about the Earth,

its natural and living resources, natural hazards, and the environment-visit

http://uww.usgs.gov or call 1-888-ASK-USGS (1-888-275-8747)

For an overview of USGS information products, including maps, imagery, and publications, visit http://hww.usgs.gov/pubprod

To order this and other USGS information products, visit http://store.usgs.gov

Any use of trade, firm, or product names is for descriptive purposes only and does not imply endorsement by the U.S. Government.

Although this information product, for the most part, is in the public domain, it also may contain copyrighted materials as noted in the text. Permission to reproduce copyrighted items must be secured from the copyright owner.

Suggested citation:

Dickhudt, P.J., Sherwood, C.R., and Dewitt, N.T., 2015, Water-level measurements in Dauphin Island, Alabama, from the 2013 hurricane season: U.S. Geological Survey Open-File Report 2014-1245, 24 p.,

http://dx.doi.org/10.3133/ofr20141245. 


\section{Acknowledgments}

The authors thank Jeff Krause of Dauphin Island Sea Lab at the State of Alabama Marine Science Institution for his technical assistance at the lab and for sharing the lab and storage space. The mayor and property owners of Dauphin Island graciously allowed us to install our sensors on their property; this project could not have been completed without their generous assistance. The work detailed in this report was part of the Barrier Island Evolution Research Project of the U.S. Geological Survey (USGS). The authors thank the following USGS staff for their assistance: Joe Long and Soupy Dalyander for help with site selection and sensor installation; Kristy Guy for preparing the visually appealing site maps; and B.J. Reynolds for assistance recovering gear and surveying the sensor elevations. 



\section{Contents}

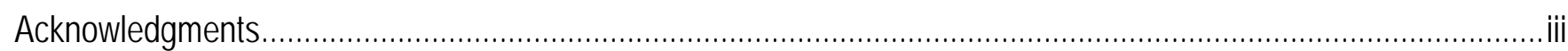

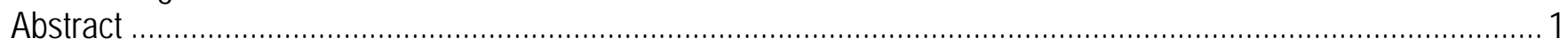

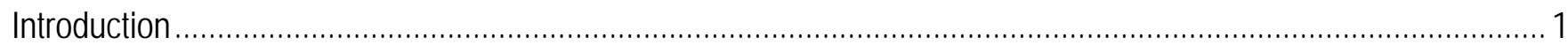

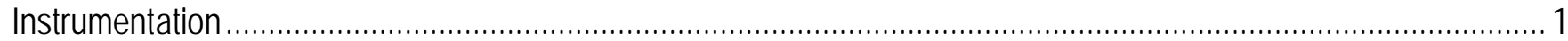

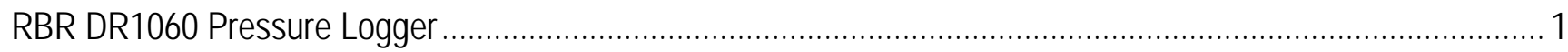

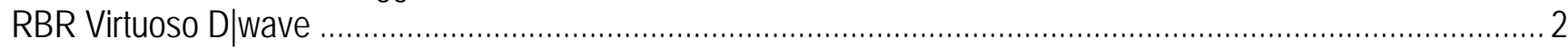

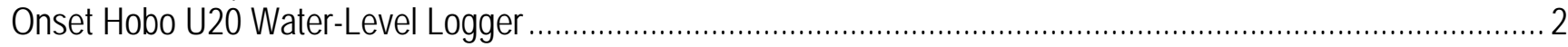

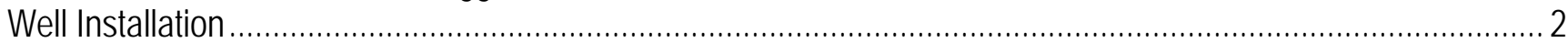

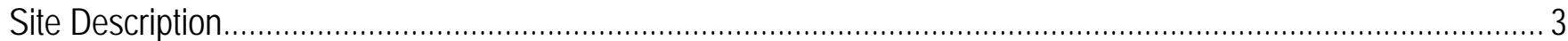

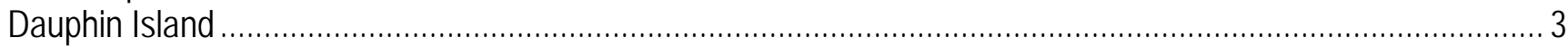

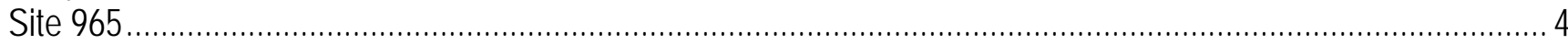

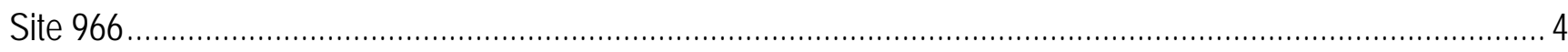

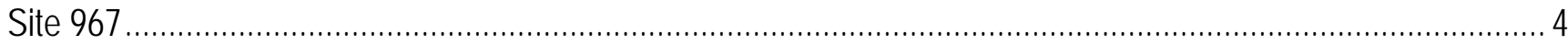

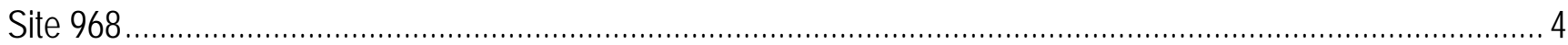

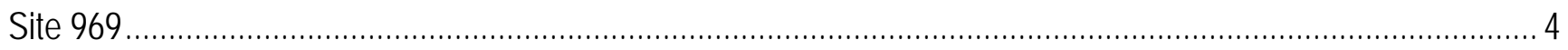

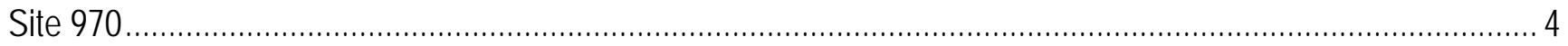

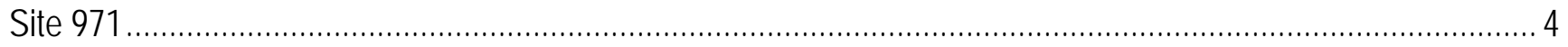

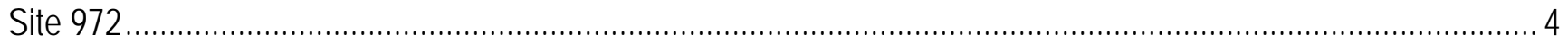

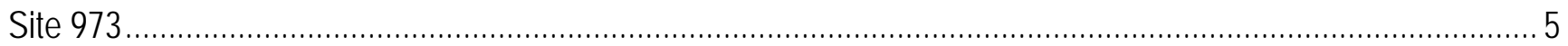

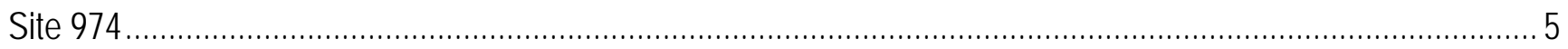

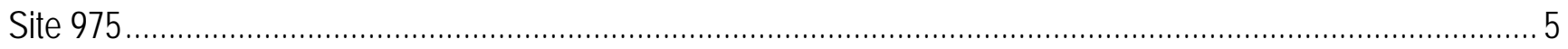

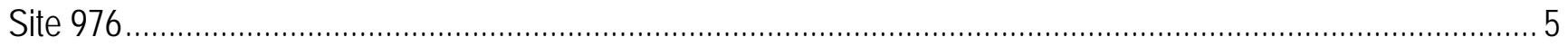

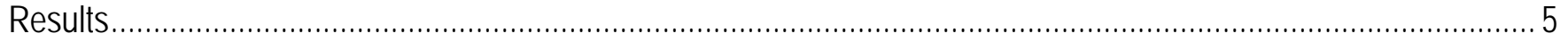

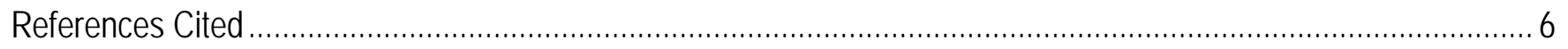

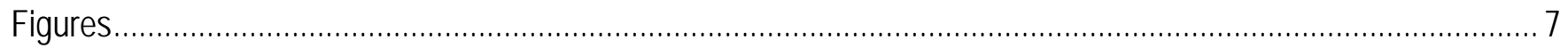

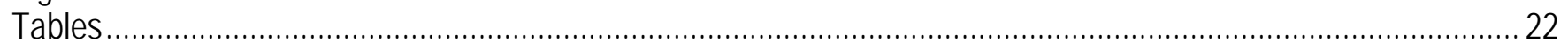

\section{Figures}

1. Locations of sites on Dauphin Island, Alabama, used to monitor water levels, atmospheric pressure, and temperatures from July 22 through November 20, 2013 ................................................................ 7

2. Photographs of RBR DR1060 pressure logger used on Dauphin Island, Alabama, in 2013........................ 8

3. Photograph of the RBR Virtuoso D|wave sensor used on Dauphin Island, Alabama, in 2013 ..................... 9

4. Photograph of one of the Onset Hobo U20 pressure loggers and threaded stainless-steel rod used on Dauphin Island, Alabama, in 2013 ....................................................................................... 10

5. Photographs illustrating the procedure for the installation of a buried well on Dauphin Island, Alabama, in

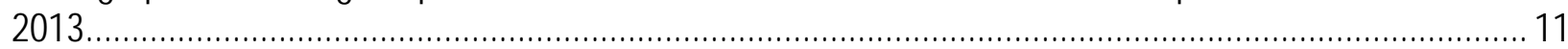

6. Photographs of well casings strapped to pilings of porches on Dauphin Island, Alabama, in 2013 ............ 12

7. Photographs of Global Position System (GPS) base station and rover on Dauphin Island, Alabama, in

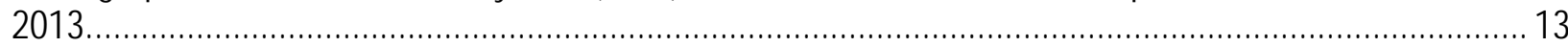

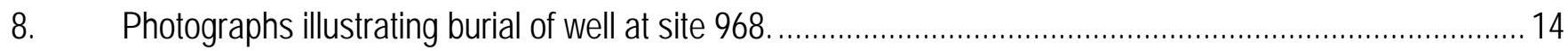

9. Atmospheric pressure time series from National Oceanic and Atmospheric Administration station DPIA1 and USGS measurements from an Onset Hobo U20 pressure sensor at site 965 on Dauphin Island, Alabama, in 2013. 
10. Atmospheric pressure and temperature time series from an Onset Hobo U20 atmospheric pressure sensor mounted on a residential porch railing at site 965 on Dauphin Island, Alabama, in 2013

11. Water-level time series from an RBR DR1060 pressure logger mounted in a buried well at site 966 on Dauphin Island, Alabama, in 2013

12. Water-level time series from an RBR Virtuoso D/wave pressure logger mounted in a buried well at site 968 on Dauphin Island, Alabama, in 2013

13. Water-level time series from an Onset Hobo U20 pressure logger mounted in a buried well at site 969 on Dauphin Island, Alabama, in 2013

14. Water-level time series from an RBR DR1060 pressure logger mounted in a buried well at site 970 on Dauphin Island, Alabama, in 2013

15. Water-level time series from an RBR DR1060 pressure logger mounted in a buried well at site 971 on Dauphin Island, Alabama, in $2013 . . .$.

16. Water-level time series from an RBR DR1060 pressure logger mounted in a buried well at site 972 on Dauphin Island, Alabama, in 2013.

17. Water-level time series from an Onset Hobo U20 pressure logger mounted in a buried well at site 973 on Dauphin Island, Alabama, in 2013

18. Water-level time series from an Onset Hobo U20 pressure logger mounted in a buried well at site 974 on Dauphin Island, Alabama, in 2013

19. Water-level time series from an Onset Hobo U20 pressure logger mounted in a buried well at site 975 on Dauphin Island, Alabama, in 2013.

20. Water-level time series from an Onset Hobo U20 pressure logger mounted in a buried well at site 976 on Dauphin Island, Alabama, in 2013

\section{Tables}

1. Mooring log sensor, location, and deployment information..... 22

2. National Oceanic and Atmospheric Administration benchmarks on Dauphin Island, Alabama..... 23

3. Instrumentation and data files for measuring water levels, atmospheric pressure, and temperature at Dauphin Island, Alabama. 


\section{Conversion Factors}

SI to Inch/Pound

\begin{tabular}{|c|c|c|}
\hline Multiply & By & To obtain \\
\hline \multicolumn{3}{|r|}{ Pressure } \\
\hline kilopascal (kPa) & 0.0099 & atmosphere, standard (atm) \\
\hline kilopascal (kPa) & 0.01 & bar \\
\hline kilopascal (kPa) & 0.296 & inch of mercury at $60^{\circ} \mathrm{F}$ (in $\mathrm{Hg}$ ) \\
\hline kilopascal (kPa) & 0.145 & pound-force per square inch (lbf/in²) \\
\hline kilopascal (kPa) & 20.89 & pound per square foot $\left(\mathrm{lb} / \mathrm{ft}^{2}\right)$ \\
\hline \multicolumn{3}{|r|}{ Length } \\
\hline centimeter $(\mathrm{cm})$ & 0.3937 & inch (in.) \\
\hline millimeter (mm) & 0.03937 & inch (in.) \\
\hline meter $(\mathrm{m})$ & 3.281 & foot $(\mathrm{ft})$ \\
\hline kilometer (km) & 0.6214 & mile (mi) \\
\hline kilometer (km) & 0.5400 & mile, nautical (nmi) \\
\hline meter (m) & 1.094 & yard (yd) \\
\hline
\end{tabular}

Temperature in degrees Celsius $\left({ }^{\circ} \mathrm{C}\right)$ may be converted to degrees Fahrenheit $\left({ }^{\circ} \mathrm{F}\right)$ as follows:

${ }^{\circ} \mathrm{F}=\left(1.8 \mathrm{x}^{\circ} \mathrm{C}\right)+32$

The SI unit for pressure is the pascal (Pa). $1 \mathrm{~Pa}=0.0001$ decibar (dbar) $=0.001$ kilopascal $(\mathrm{kPa})$.

Vertical coordinate information is referenced to North American Vertical Datum of 1988 (NAVD88).

Horizontal coordinate information is referenced to North American Datum of 1983 (NAD83).

Elevation, as used in this report refers, to distance above the vertical datum. 



\title{
Measurements in Dauphin Island, Alabama, From the 2013 Hurricane Season
}

By Patrick J. Dickhudt, Christopher R. Sherwood, and Nancy T. Dewitt

\begin{abstract}
This report describes the instrumentation, field measurements, and processing methods used by the U.S. Geological Survey to measure atmospheric pressure, water levels, and waves on Dauphin Island, Alabama, in 2013 at part of the Barrier Island Evolution Research project. Simple, inexpensive pressure sensors mounted in shallow wells were buried in the beach and left throughout the hurricane season. Additionally, an atmospheric pressure sensor was mounted on the porch of a private residence to provide a local atmospheric pressure measurement for correcting the submerged pressure records.
\end{abstract}

\section{Introduction}

The U.S. Geological Survey (USGS) measured atmospheric pressure, water levels, and waves on Dauphin Island, Alabama, from July 22 through November 20, 2013, as part of the Barrier Island Evolution Research (BIER) Project, which aims to assess the effects of individual, short-term storms on the historical and geological evolution of the coastal system. Barrier islands are dynamic systems that can experience substantial morphological change (erosion and deposition) during storms. Water levels around barrier islands are influenced by winds, waves, and atmospheric pressure during the passage of storms, and the morphological effects of storms depend, in part, on the magnitude of inundation and water-level gradients across the island. Direct water-level measurements on barrier islands during storms are somewhat uncommon because equipment is often lost, buried, or destroyed during these high-energy events.

This report describes the instrumentation, field methods, and data processing techniques used to measure water levels and waves with relatively inexpensive pressure sensors in a rapidly evolving barrier island system (fig. 1). These water-level and wave measurements can be used to validate numerical models and help interpret the morphological response of barrier islands to storms.

\section{Instrumentation}

\section{RBR DR1060 Pressure Logger}

The RBR DR1060 (fig. 2) is a small submersible pressure logger capable of recording more than 2 million samples at frequencies up to 1 hertz $(\mathrm{Hz})$. These pressure loggers were temperature compensated and had pressure sensors with a depth rating of 10 meters (m). The manufacturer-specified accuracy was \pm 0.05 percent of full scale (about 0.005 -m water depth) and resolution was 0.001 percent of full scale (about 0.0001-m water depth). Each RBR DR1060 was mounted on a rigid metal rod connected to the cap of a buried well jetted into the beach (described in "Well Installation"). The RBR 
DR1060s recorded pressure every 5 seconds. At this sample rate, the RBR DR1060s could sample for about 5 months before running out of memory.

\section{RBR Virtuoso D|wave}

The RBR Virtuoso D|wave (fig. 3) is a small submersible pressure logger capable of sampling continuously or in burst mode at speeds up to $6 \mathrm{~Hz}$ and can store 30 million individual readings. This unit was temperature compensated and had a pressure sensor with a depth rating of $10 \mathrm{~m}$. The manufacturer-specified accuracy was \pm 0.05 percent of full scale (about $0.005 \mathrm{~m}$ water depth) and resolution was 0.001 percent of full scale (about $0.0001 \mathrm{~m}$ water depth). The RBR Virtuoso $\mathrm{D} \mid$ wave was mounted on a rigid metal rod connected to the cap of a buried well jetted into the beach next to a piling of a residential porch (described in "Well Installation"). The well casing was secured to the porch piling with hose clamps and ratchet straps. The D|wave recorded pressure measurements continuously at $4 \mathrm{~Hz}$ from July 21, 2013, until its batteries died on October 24, 2013.

\section{Onset Hobo U20 Water-Level Logger}

The Onset Hobo U20 water-level logger (fig. 4) is a small submersible pressure logger capable of recording about 22,000 pressure and temperature samples at rates up to $1 \mathrm{~Hz}$. Two models of Onset Hobo U20s were deployed: model U20-001-04 pressure sensors with ranges of 0 to 15 decibars (about 0-4 m water depth) were used as atmospheric and submersible sensors; and model U20-001-01 pressure sensors with ranges of 0 to 21 decibars (about 0-9 m water depth) were used as submerged sensors. The U20-001-04 sensor has a water-level accuracy of \pm 0.075 percent of full scale (about 0.003 $\mathrm{m}$ water depth) and water-level resolution of $0.001 \mathrm{~m}$ water depth. The U20-001-01 used as a submerged sensor has a water-level accuracy of 0.05 percent of full scale (about 0.005-m water depth) and water-level resolution of $0.002 \mathrm{~m}$ water depth.

The U20-001-04 sensor used as an atmospheric sensor was mounted in a small white PVC tube with vents, and attached with hose clamps to the railing of a residential porch. The sensor was mounted about $4 \mathrm{~m}$ above ground level. The submerged Onset Hobo U20s were mounted on rigid metal rods connected to the cap of buried wells jetted into the beach (described in "Well Installation"). Each Onset Hobo U20 collected a pressure measurement every 600 seconds for the duration of the deployment. At this sample rate, the Onset Hobo U20s could sample for about 5 months before running out of memory.

\section{Well Installation}

The Onset Hobo and RBR DR1060 pressure sensors buried in the beach were encased in 4.8centimeter (cm; outside diameter) schedule 80 polyvinyl chloride (PVC) slotted well screen. The RBR Virtuoso D|wave had a larger diameter and was encased in an 8.9-cm (outer diameter) schedule 80 PVC slotted well screen. The well casings were about $1.5 \mathrm{~m}$ long and were screened with 0.15 -millimeter (mm)-wide slots along most of their length. A PVC well point with a $1.25 \mathrm{~cm}$ diameter hole drilled through its center (to allow a water jet to exit) was screwed on to the lower end of each well. Wells were installed by first digging a shallow hole (30 to $50 \mathrm{~cm}$ deep) and then using a 2.54-cm (1-inch) gasolinepowered water pump to jet the well into the sand until the top of the well was below the level of the beach (fig. 5). A pressure sensor was hung from a threaded rod attached to a PVC cap that screwed into the top of the well after jetting. The distance from the well cap to the pressure sensor is provided in table 1 and approximates the pressure-sensor depth below the sediment surface. Wells on the Gulf of Mexico side (mooring numbers 968, 970, and 971) were in an energetic surf zone setting (fig. 6A) and were 
jetted into the beach next to the pilings of waterfront residences and secured to the pilings with hose clamps and ratchet straps (fig. 6A and B).

The elevation of the well cap was established using post-processed static Global Positioning System (GPS) data. A GPS base station was placed on the National Geodetic Survey (NGS) tidal benchmark PID BH1755 at the entrance into Fort Gains on the east end of Dauphin Island, and a GPS rover unit was used to survey the wells. The error between the base and the rover increased exponentially with distance from the base station (Waypoint Consulting Inc., 2005) as reflected by an increase in the root mean squared (RMS) error of the differentially corrected navigation data. All wells were within 12 kilometers of the base station.

The GPS base station and the rover were duplicate systems with Ashtech Z-Xtreme GPS receivers, internal data recorders, Thales choke-ring antennae, and tripods (fig. 7A). After the wells were installed, the GPS rover was positioned and referenced to a dimple on the well cap (fig. 7B). Both receivers recorded the 12-channel full-carrier-phase positioning signals (L1/L2) from the satellites and recorded their positions concurrently at 1-second (s) intervals for at least 30 minutes (min). This 30-min GPS static occupation session was repeated when the wells were recovered months later.

All GPS static sessions were processed using NovAtel GrafNet version 8.4 software, accounting for antenna height, antenna model, and GPS session type (rover or base). The NGS-published latitude, longitude, and ellipsoid height referenced to the North American Datum 1983 (NAD83) were transformed into World Geodetic System 1984 (WGS84; G1150) using the NGS Horizontal TimeDependent Positioning (HTDP) version 3.2.3 utility for postprocessing purposes (table 2). The processed position heights were referenced to the top of the well cap and converted to NAD83 (CORS96) using the NGS HTDP utility. These processed heights were then processed through the NGS GEOID96 model to obtain geoid heights. The elevation of the pressure sensor was then determined by subtracting the distance from the well cap to the pressure sensor (table 1) from the cap elevation.

The uncertainty of the elevation of the water-level sensor was estimated by using the square root of the sum of the squared individual error terms. The individual error terms included difference in surveyed well cap heights as measured upon deployment and recovery, the estimated error in the length of the threaded rods the sensors were suspended from, and the standard deviation of the GPS elevation measurements for a particular well. In addition, for wells on the Gulf of Mexico side of Dauphin Island that were strapped to porch pilings, the error in the measured distance from the well cap to a surveyed mark on the porch was included. The estimated uncertainty in the water-level sensor elevations ranged from 0.008 to $0.036 \mathrm{~m}$ (table 1 ).

\section{Site Description}

\section{Dauphin Island}

Dauphin Island is a populated, low-lying barrier island in the northern Gulf of Mexico (fig. 1). It is bordered by Mobile Bay to the east, Mississippi Sound to the north and west, and the Gulf of Mexico to the south. Dauphin Island is frequently exposed to the force of hurricanes from the Gulf of Mexico, the most recent of which was Hurricane Katrina in 2005, which breached the western portion of the island. 


\section{Site 965}

Site 965 was at a residence off St. Stephens Street. An Onset Hobo U20-001-04 atmospheric pressure sensor was mounted in a PVC tube that was hose clamped to the second floor porch railing of the residence.

\section{Site 966}

Site 966 was in a small channel in an empty lot on the Mississippi Sound side of the island about $200 \mathrm{~m}$ to the west of St. Stephens Street. An RBR DR1060 pressure sensor was mounted in a well buried in the beach.

\section{Site 967}

Site 967 was on the beach on the Mississippi Sound side of the island and to the north of the public parking lot at the western end of the island. An RBR DR1060 pressure sensor was mounted in a well buried in the beach. The sensor at site 967 could not be located for recovery, so the data were lost.

\section{Site 968}

Site 968 was on the Gulf of Mexico side of the island at a residence on Bienville Boulevard. An RBR Virtuoso D|wave was mounted in a well buried in the beach and strapped to a piling on the southeastern side of the residence. The piling the instrument was strapped to was in the swash zone of the beach at high tide when the instrument was deployed. About 0.6 to $0.8 \mathrm{~m}$ of sediment had accumulated at this site between deployment and recovery, completely burying the well (fig. 8) and making recovery difficult.

\section{Site 969}

Site 969 was on the Mississippi Sound side of the island in a small channel near Sam Houston Road. An Onset Hobo U20-001-01 pressure sensor was mounted in a well buried in the beach.

\section{Site 970}

Site 970 was on the Gulf of Mexico side of the island at a residence on Bienville Boulevard. An RBR DR1060 was mounted in a well buried in the beach and strapped to a piling on the southeastern side of the residence.

\section{Site 971}

Site 971 was on the Gulf of Mexico side of the island at a residence on Seneca Street. An RBR DR1060 was mounted in a well buried in the beach and strapped to a piling on the southwestern side of the residence.

\section{Site 972}

Site 972 was along the beach on the Mississippi Sound side of the island. An RBR DR1060 pressure sensor was mounted in a well buried in the beach. 


\section{Site 973}

Site 973 was directly between sites 971 and 972 in the middle of the island. An Onset Hobo U20-001-04 pressure sensor was mounted in a well buried in the sand.

\section{Site 974}

Site 974 was in the middle of the island between sites 967 and 968 in a lot behind a home on Bienville Boulevard. An Onset Hobo U20-001-01 pressure sensor was mounted in a well buried in the sand.

\section{Site 975}

Site 975 was in the middle of the island in a channel in an empty lot just off St. Stephens Street and between sites 966 and 970. An Onset Hobo U20-001-04 pressure sensor was mounted in a well buried in the sand.

\section{Site 976}

Site 976 was along the beach on the Mississippi Sound side of the island very near the inlet of the canal next to St. Stephens Street. An Onset Hobo U20-001-01 pressure sensor was mounted in a well buried in the beach. Sometime before recovery, a large pile of sand (about $1 \mathrm{~m}$ high by $2 \mathrm{~m}$ in diameter) was placed over the sensor location and had to be removed so the instruments could be recovered.

\section{Results}

Atmospheric pressure data were collected continuously from July 22 to November 20, 2013, by the sensor mounted at site 965 . The data appear to be of good quality but differ at times from data collected by the nearest land-based atmospheric pressure sensors. Specifically, the sensor at 965 shows larger variations in pressure than the sensors at National Oceanic and Atmospheric Administration (NOAA) gauge DPIA1, approximately 7 kilometers (km) east of site 965 (fig. 9). These pressure excursions may be real (for example, due to short-term pressure fluctuations caused by frontal passages) or they may be artifacts of sensor exposure to sun and wind. Figure 10 is a time-series plot of atmospheric pressure and temperature from site 965.

Pressure sensors encased in wells buried in the beach were deployed from July 2013 through November 2013 (table 1). All data from the wells were of very high quality with no evidence of error due to fouling or attenuation from burial. One sensor (at site 967) could not be located and was never recovered, so there are no data for that site. Three sensors stopped sampling early due to battery failure. The RBR D|wave sensor at site 968 stopped operating on October 24, the RBR DR1060 sensor at site 970 stopped operating on August 28, and the RBR DR1060 sensor at site 972 stopped operating on October 3.

Water levels were derived from the well pressure sensors by subtracting atmospheric pressure linearly interpolated (in time) from measurements taken every 60 minutes at NOAA gauge DPIA1. The corrected pressure data were converted from decibars to water depth using an assumed seawater density of 1022.3 kilograms per cubic meter (calculated from salinity of 34 practical salinity units and temperature of 26 degrees Celsius, a typical salinity and approximately the mean temperature) and 
adjusted to a common datum (North American Vertical Datum of 1988 [NAVD88]) using the surveyed cap elevation and the measured distance from the cap to the pressure sensor (table 1). Time series plots of water-level data from the buried wells are shown in figures 11 through 20 . In the water-level plots, the reported water level is NAVD88 orthometric height referenced to the NGS GEOID96 datum.

Data from all instruments were converted to standard format for USGS time series (Montgomery and others, 2009) and stored in network common data format (netCDF) files. NetCDF files store data and associated metadata in a format that is compact and machine-independent. Documentation of the USGS Oceanographic Time-Series Measurement Database can be found in Open-File Report 20071194 (http://woodshole.er.usgs.gov/pubs/of2007-1194/). Details of instrumentation used for measurement of water levels, atmospheric pressure, and temperature are provided in table 3.

\section{References Cited}

Montgomery, E.T., Martini, M.A., Lightsom, F.L. and Butman, Bradford, 2009, Documentation of the U.S. Geological Survey oceanographic time series measurement database (February 2009 revision): U.S. Geological Survey Open-File Report 2007-1194, http://pubs.usgs.gov/of/2007/1194/.

Waypoint Consulting Inc., 2005, Static baseline accuracies as a function of baseline length, observation time and the effect of using the precise ephemeris: Waypoint Consulting Incorporated, 12 p., accessed September 2, 2014 at http://www.novatel.com/assets/Documents/Waypoint/Reports/Static_Accuracies.pdf. 


\section{Figures}

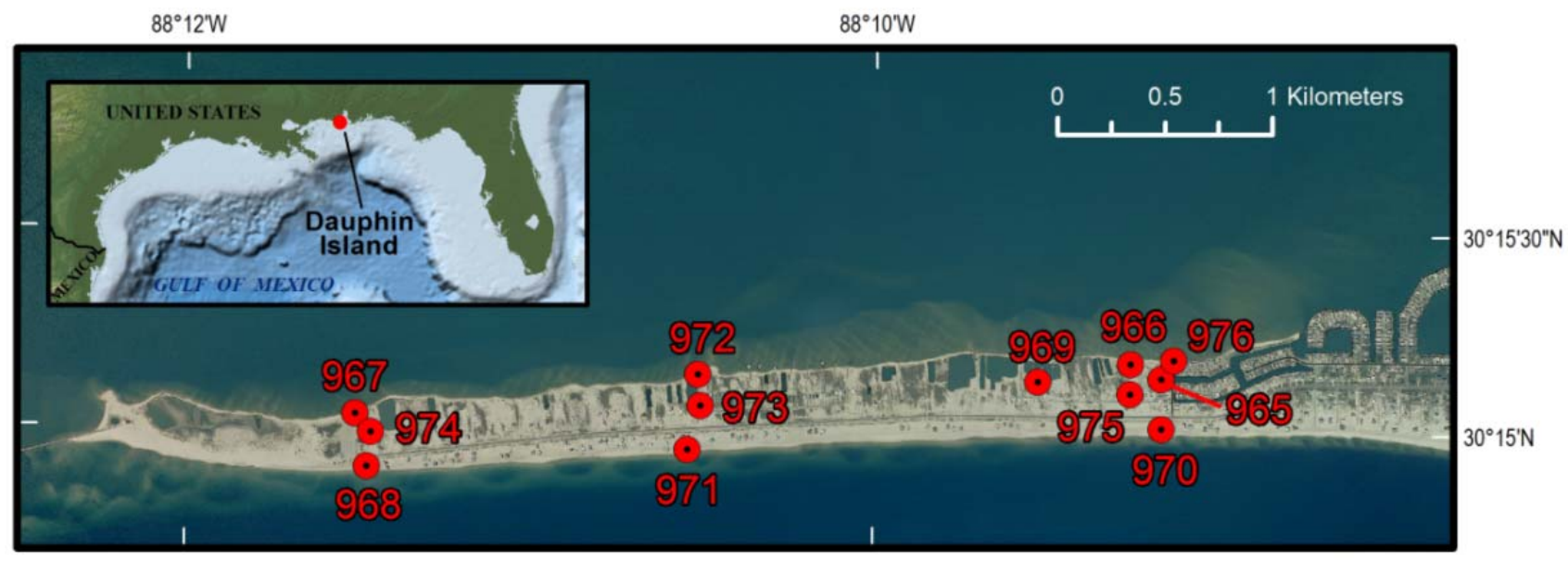

Figure 1. Locations of sites on Dauphin Island, Alabama, used to monitor water levels, atmospheric pressure, and temperatures from July 22 through November 20, 2013. Red dots on map indicate locations of sites. Inset base from the National Atlas of the United States, 2009. Aerial photo base from the U.S. Department of Agriculture, National Agricultral Imagery Program, 2011. 


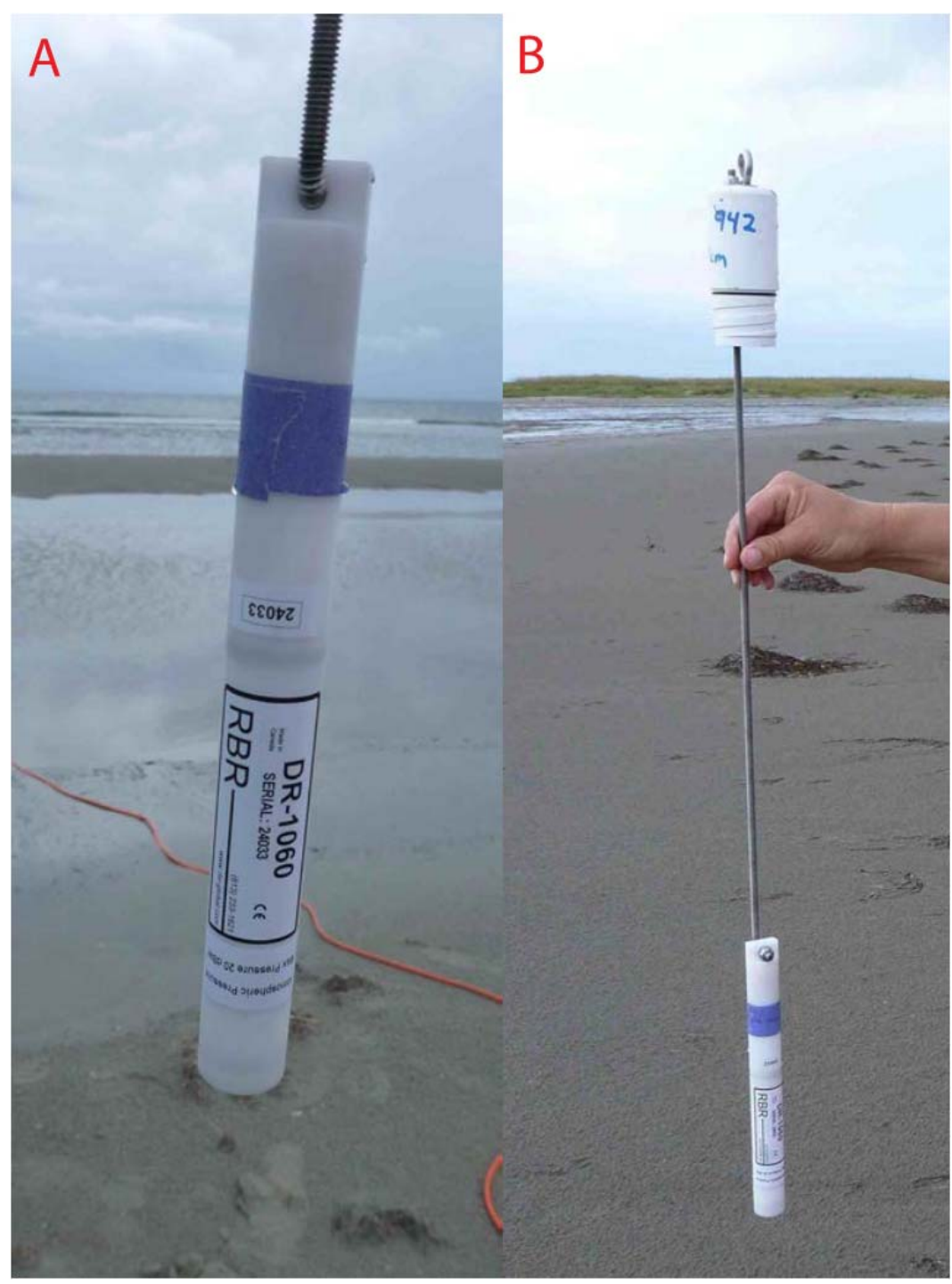

Figure 2. Photographs of RBR DR1060 pressure logger used on Dauphin Island, Alabama, in 2013. A, Close-up of RBR DR1060 pressure logger. $B$, RBR DR1060 pressure logger connected to well cap by threaded stainlesssteel rod. The pressure senor is inserted into well casing and cap is screwed onto top of well (fig. 5E). 


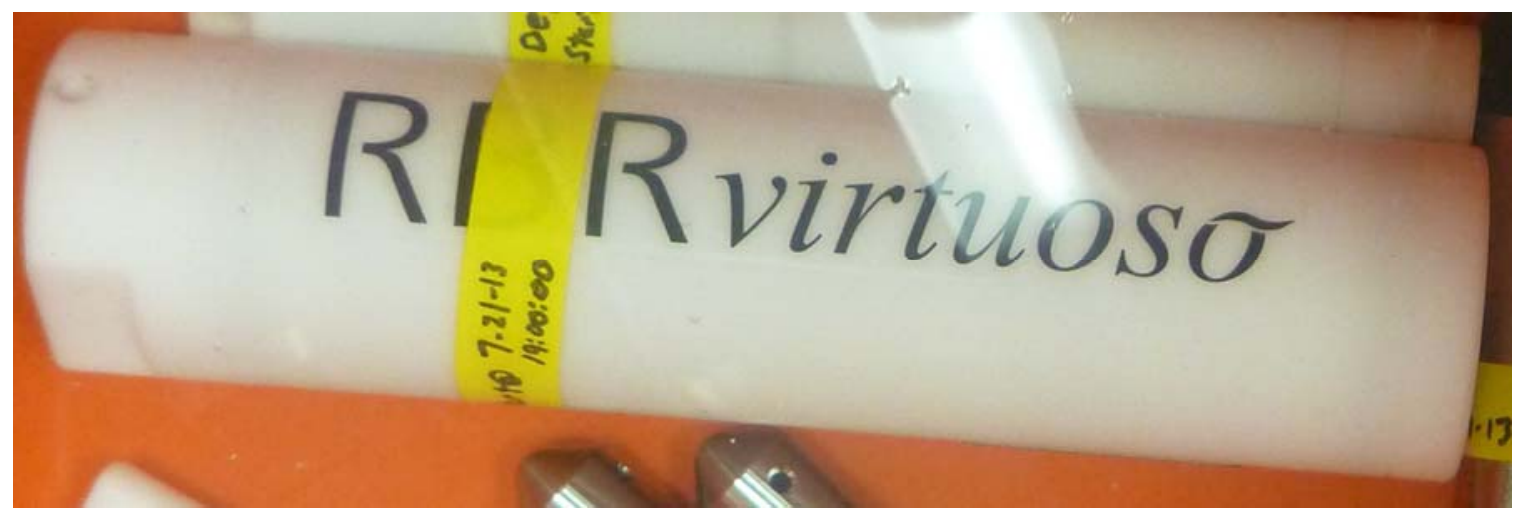

Figure 3. Photograph of the RBR Virtuoso D|wave sensor used on Dauphin Island, Alabama, in 2013. 


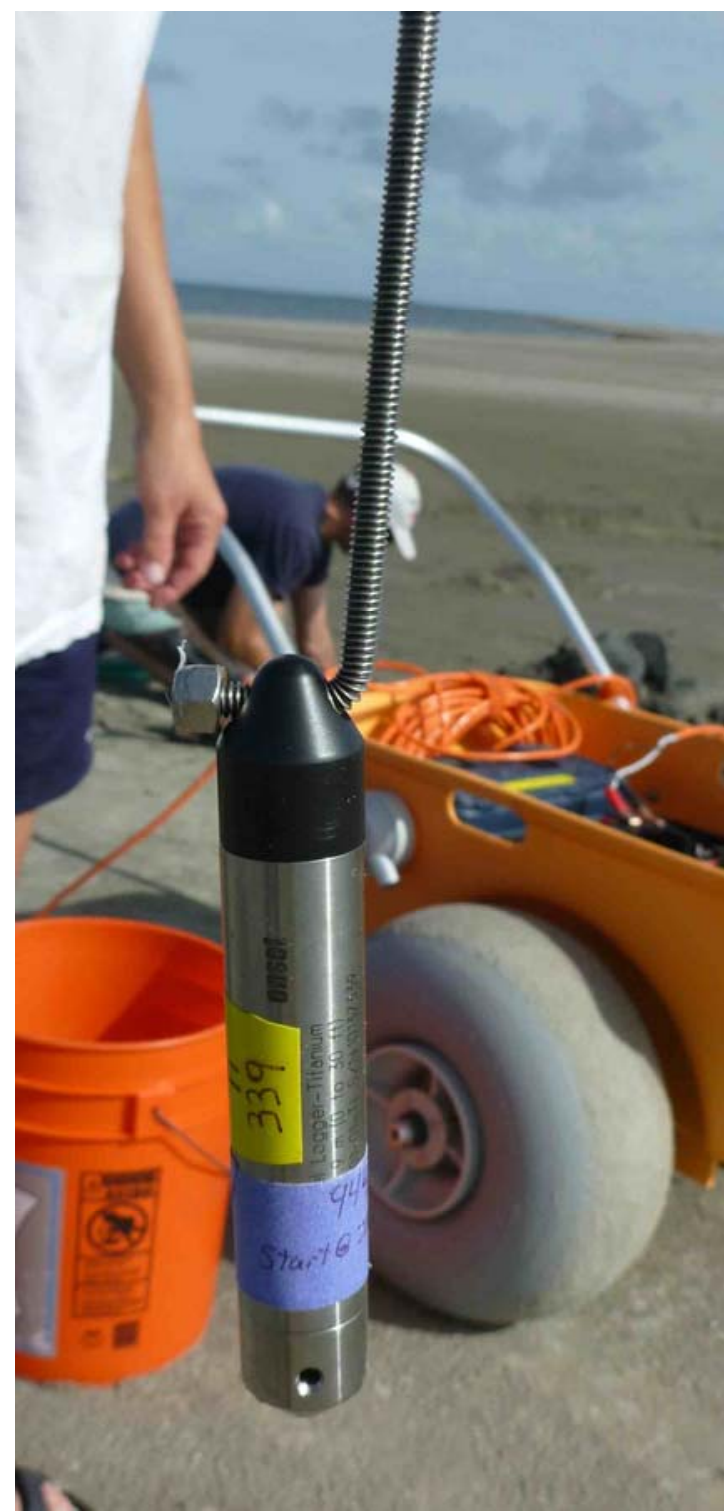

Figure 4. Photograph of one of the Onset Hobo U20 pressure loggers and threaded stainless-steel rod used on Dauphin Island, Alabama, in 2013. 


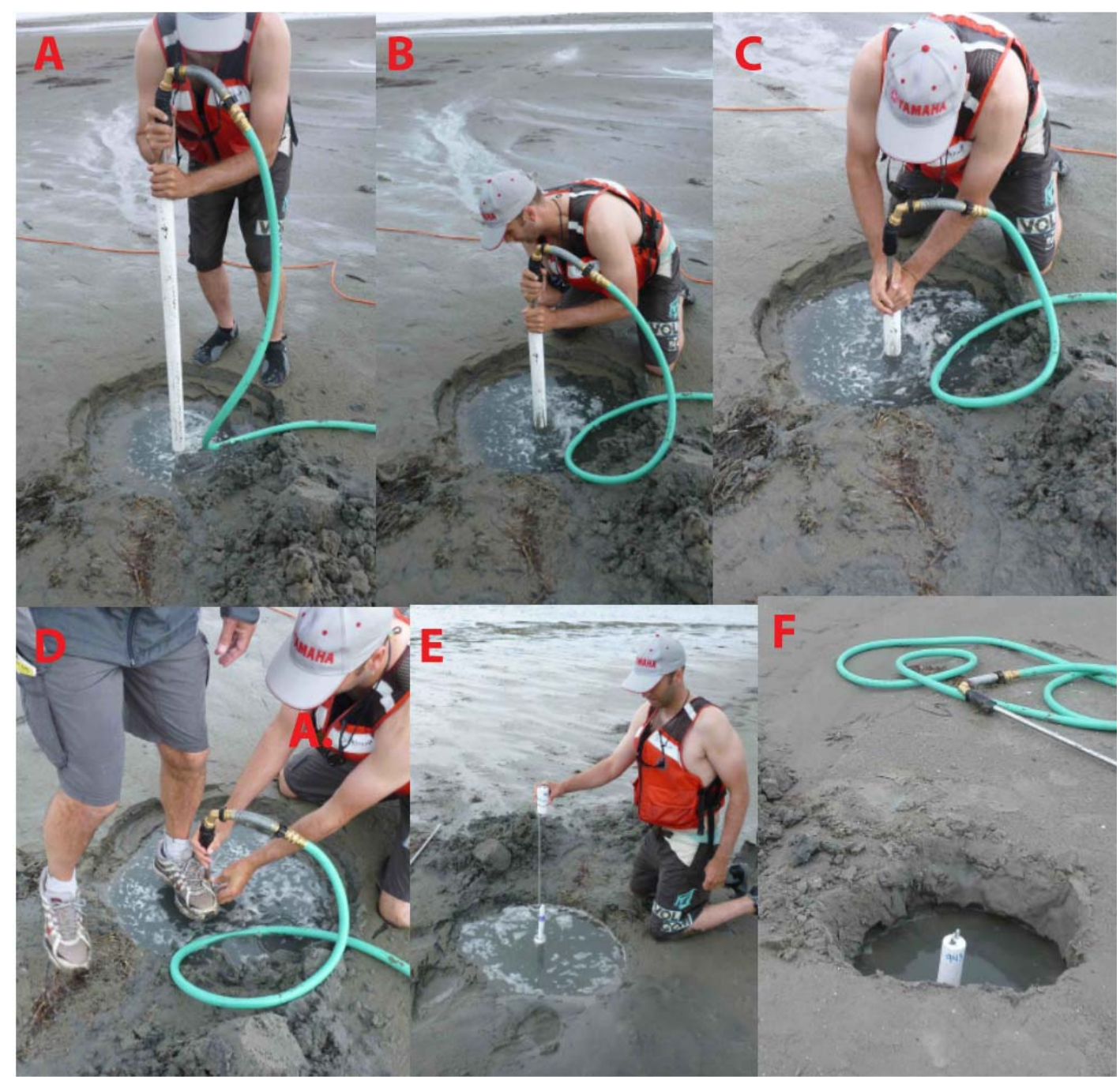

Figure 5. Photographs illustrating the procedure for the installation of a buried well on Dauphin Island, Alabama, in 2013. $A-C$, well casing being jetted into the sand; $D$, well casing at the end of jetting; $E$, pressure sensor inserted into the casing; and $F$, completed installation with pressure sensor inserted and cap screwed into the well casing. 


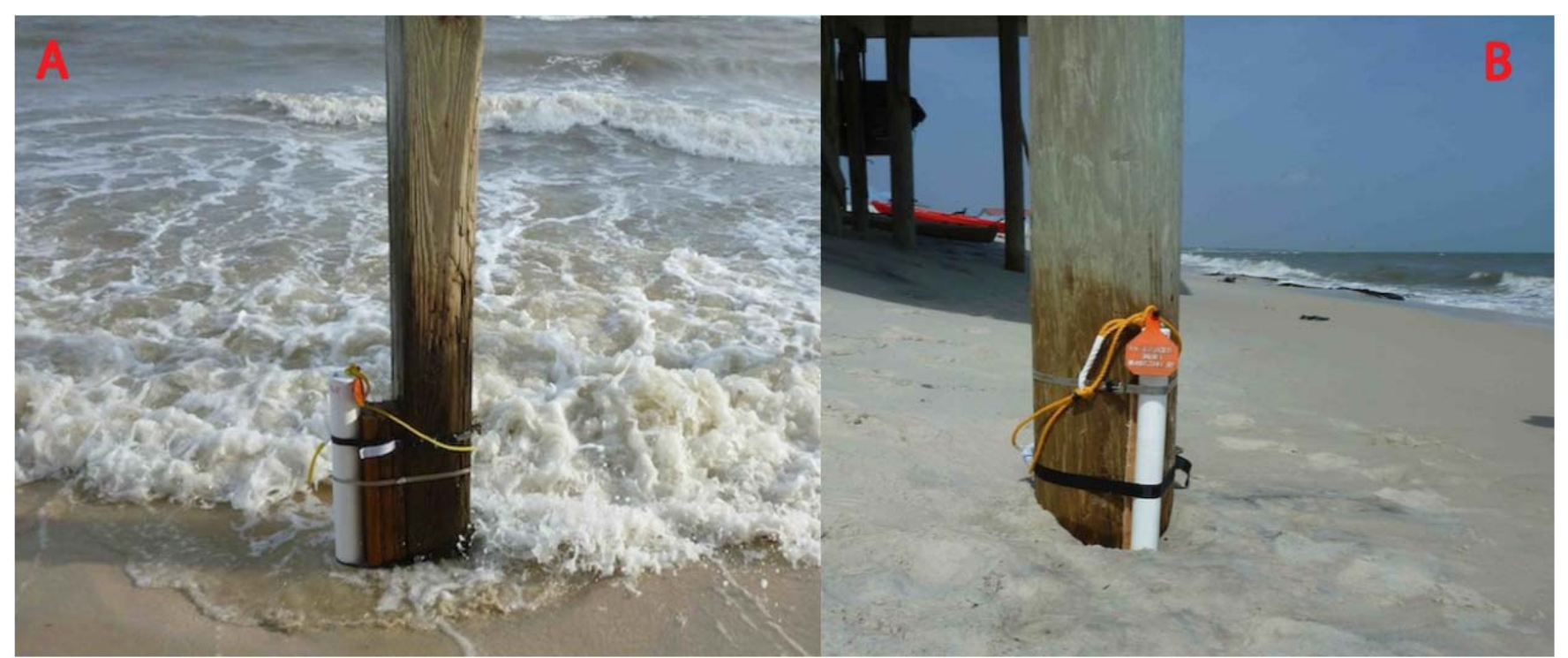

Figure 6. Photographs of well casings strapped to pilings of porches on Dauphin Island, Alabama, in 2013. A, The well casing at site 968 after being buried and strapped to a piling on the porch of a private residence. $B$, The well casing at site 971 after being buried and strapped to a porch piling. 


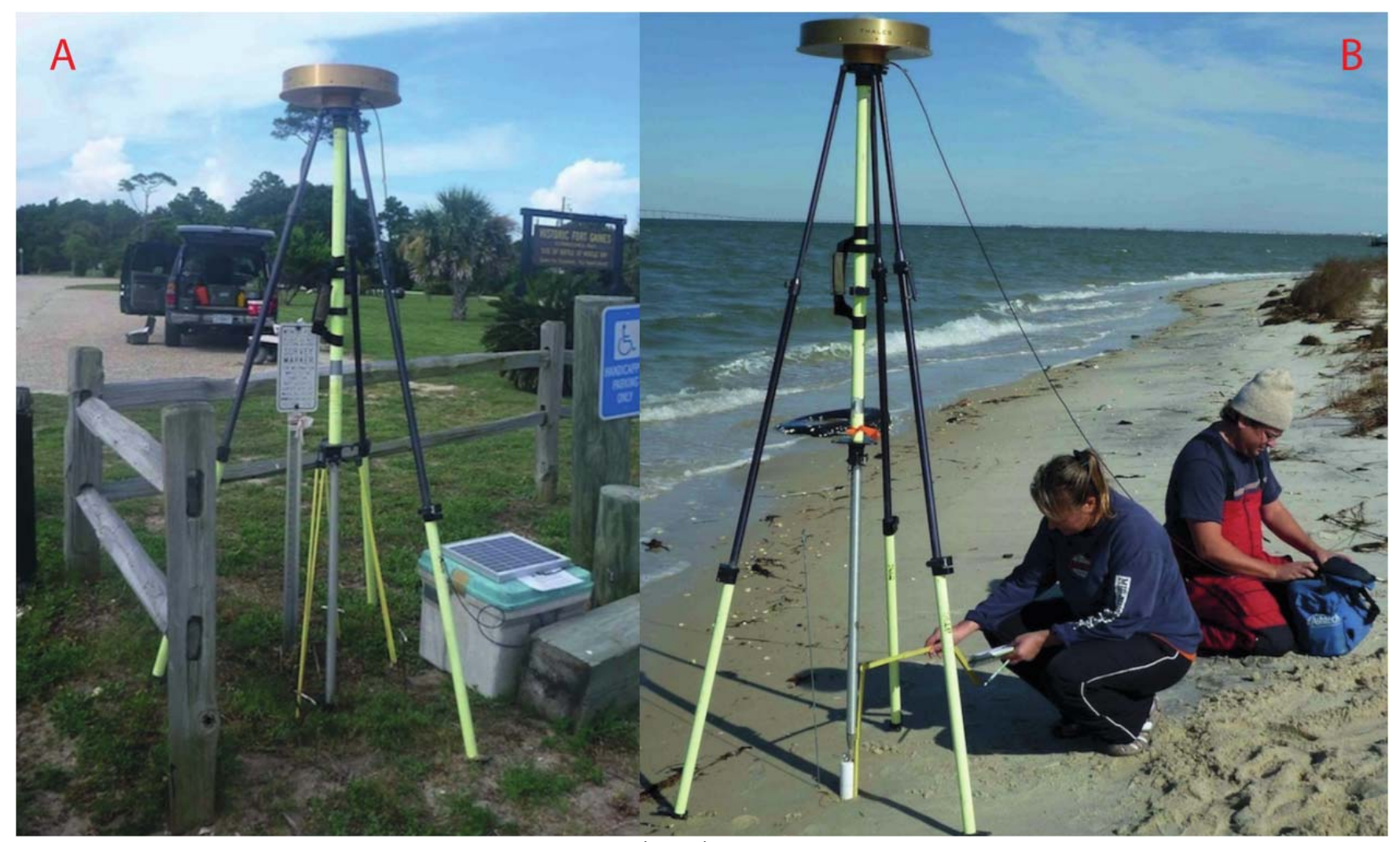

Figure 7. Photographs of Global Position System (GPS) base station and rover on Dauphin Island, Alabama, in 2013. A, Base station near the entrance of Fort Gaines on the eastern side of Dauphin Island. B, U.S. Geological Survey Scientists surveying the well at site 972 with a GPS rover before recovering the sensor from the well. Erosion of the beach on the Mississippi Sound side of the island beach between deployment and recovery left the top of the well at site 972 exposed. 


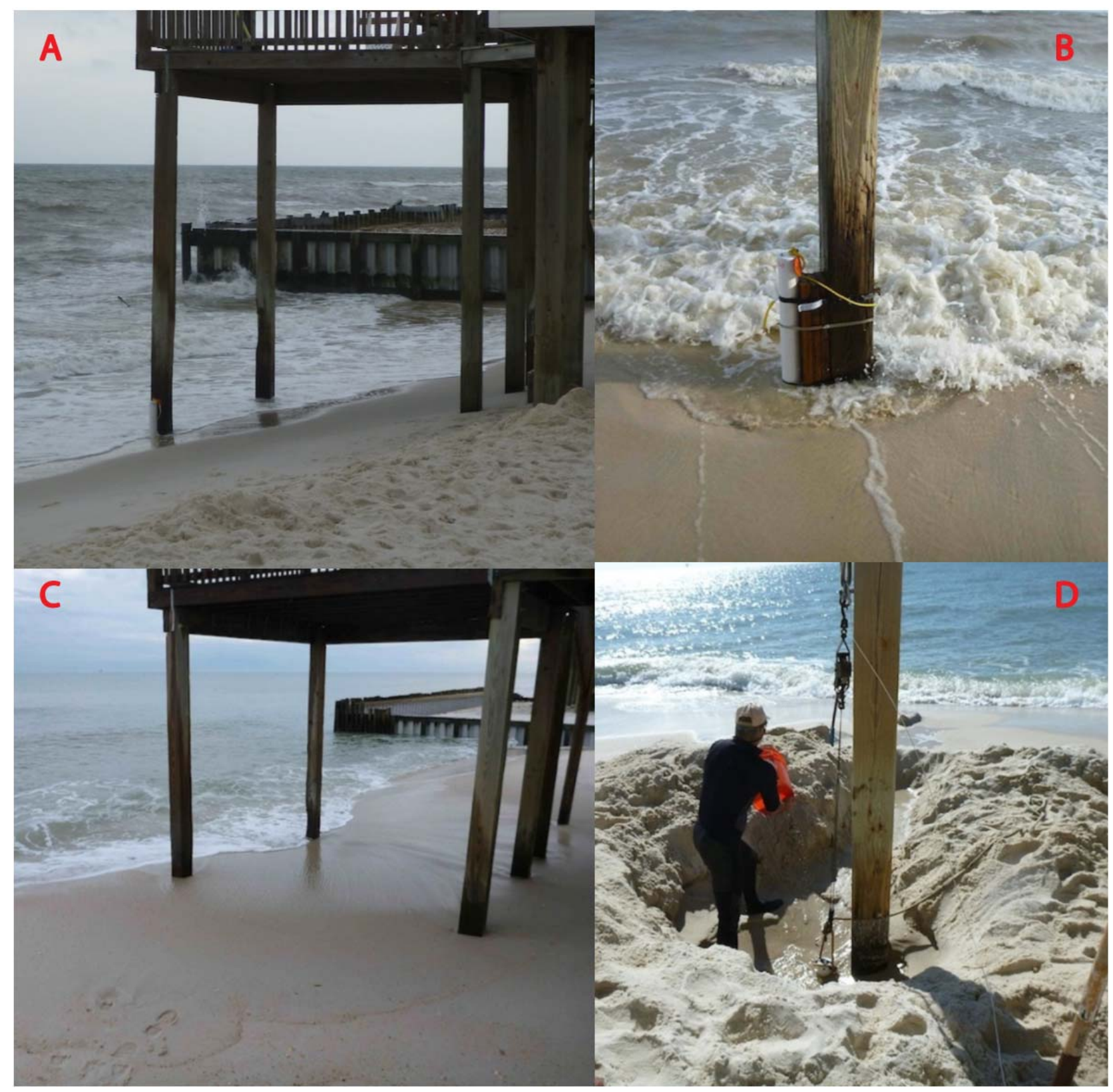

Figure 8. Photographs illustrating burial of well at site 968 . A, View of porch piling and the well at site 968 immediately after deployment; the well is at the base of the piling the farthest to the left in the picture. $B$, The well at site 968 strapped to piling shortly after deployment. $C$, View of porch piling with well completely buried just before recovering sensor from well. D, U.S. Geological Survey scientist digging out the well at site 968. 


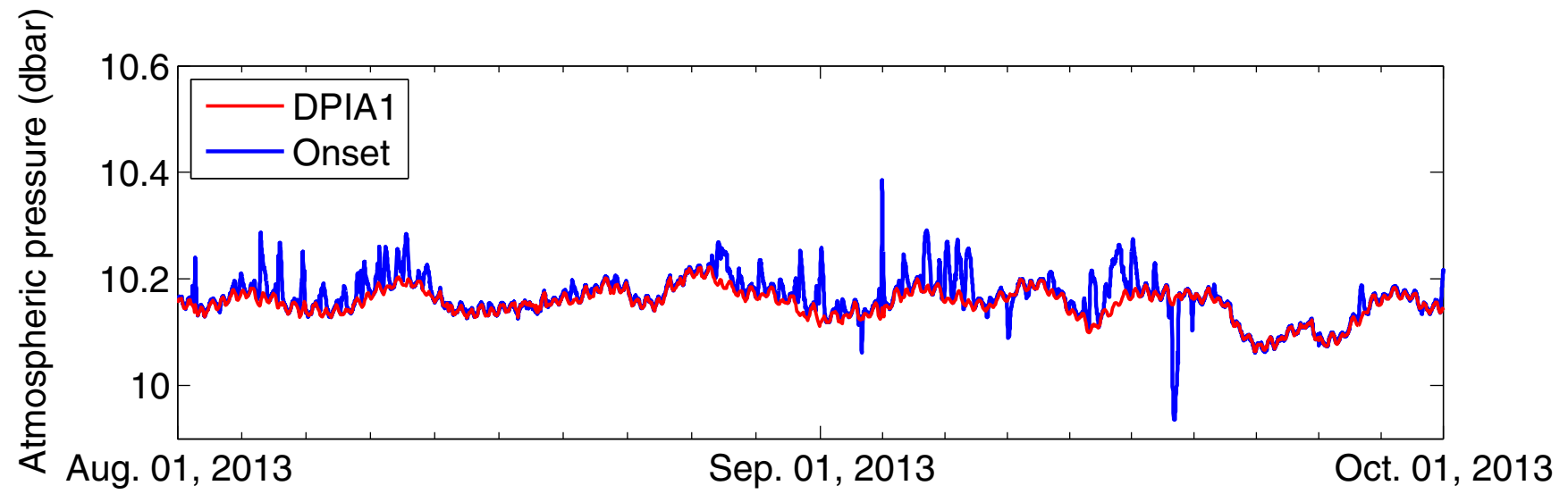

Figure 9. Atmospheric pressure time series from National Oceanic and Atmospheric Administration station DPIA1 and USGS measurements from an Onset Hobo U20 pressure sensor at site 965 on Dauphin Island, Alabama, in 2013. Although the study covered from July 22 through November 20,2013, this graph only shows August 1 through October 1, 2013, to highlight the difference between the two sensors. dbar, decibars. 

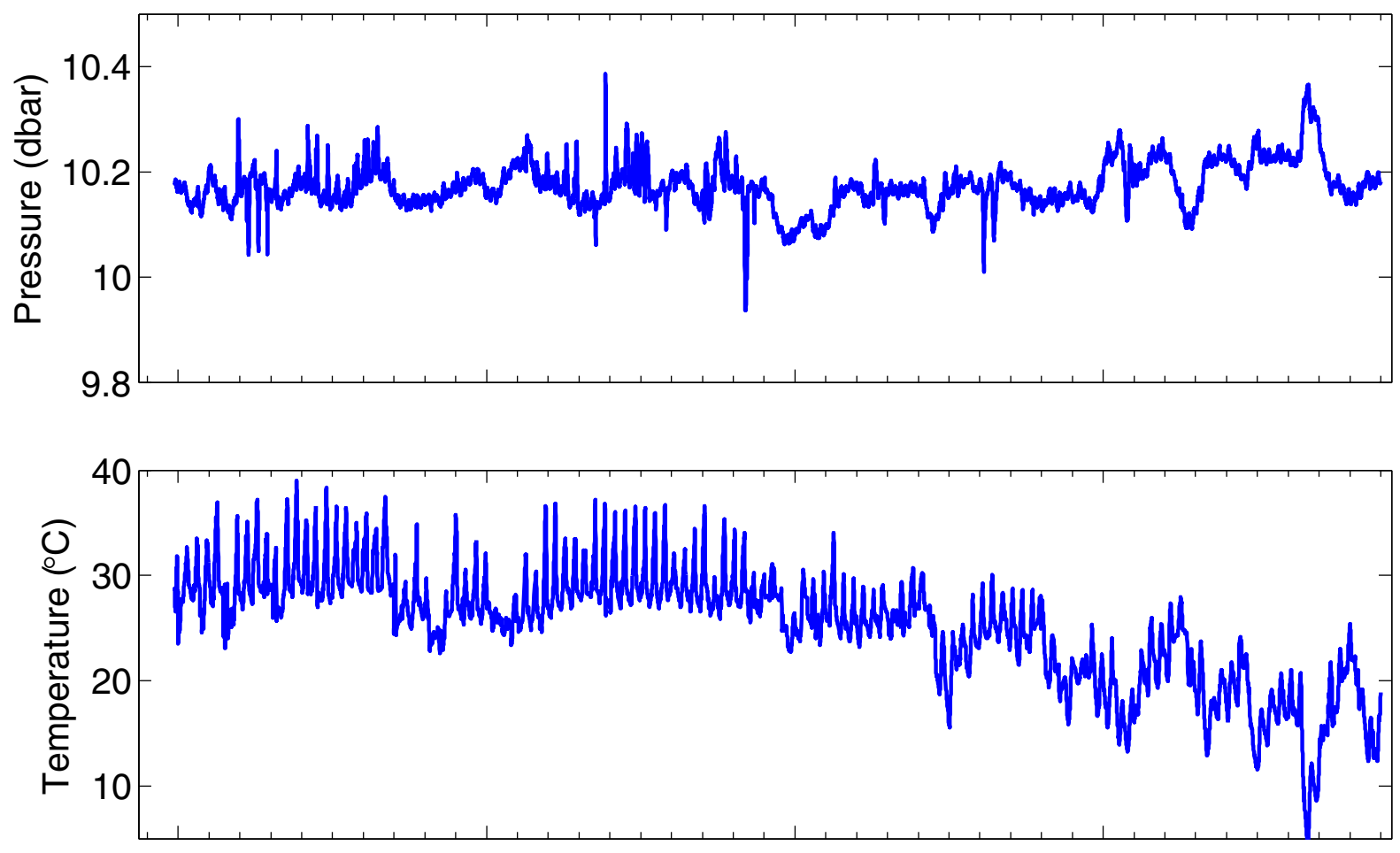

$\begin{array}{llll}\text { Jul. 23, } 2013 & \text { Aug. 23, } 2013 & \text { Sep. 23, } 2013 & \text { Oct. 24, } 2013\end{array}$

Figure 10. Atmospheric pressure and temperature time series from an Onset Hobo U20 atmospheric pressure sensor mounted on a residential porch railing at site 965 on Dauphin Island, Alabama, in 2013. dbar, decibars; ${ }^{\circ} \mathrm{C}$, degrees Celsius. 


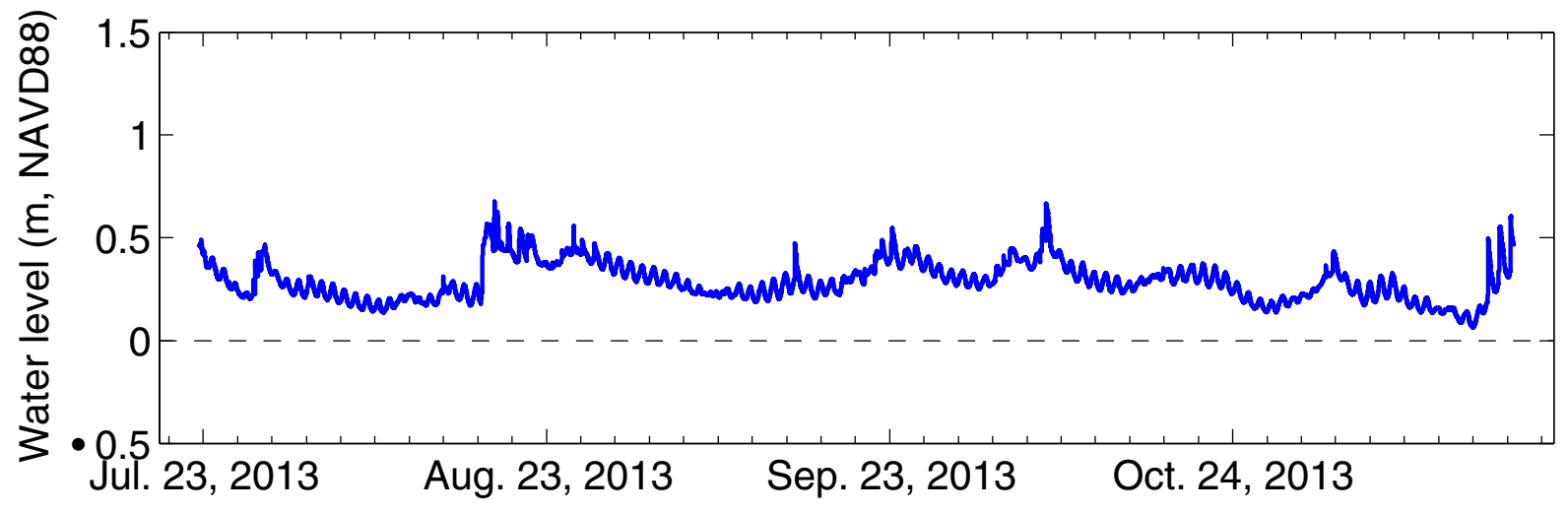

Figure 11. Water-level time series from an RBR DR1060 pressure logger mounted in a buried well at site 966 on Dauphin Island, Alabama, in 2013. m, meters; NAVD88, North American Vertical Datum of 1988.

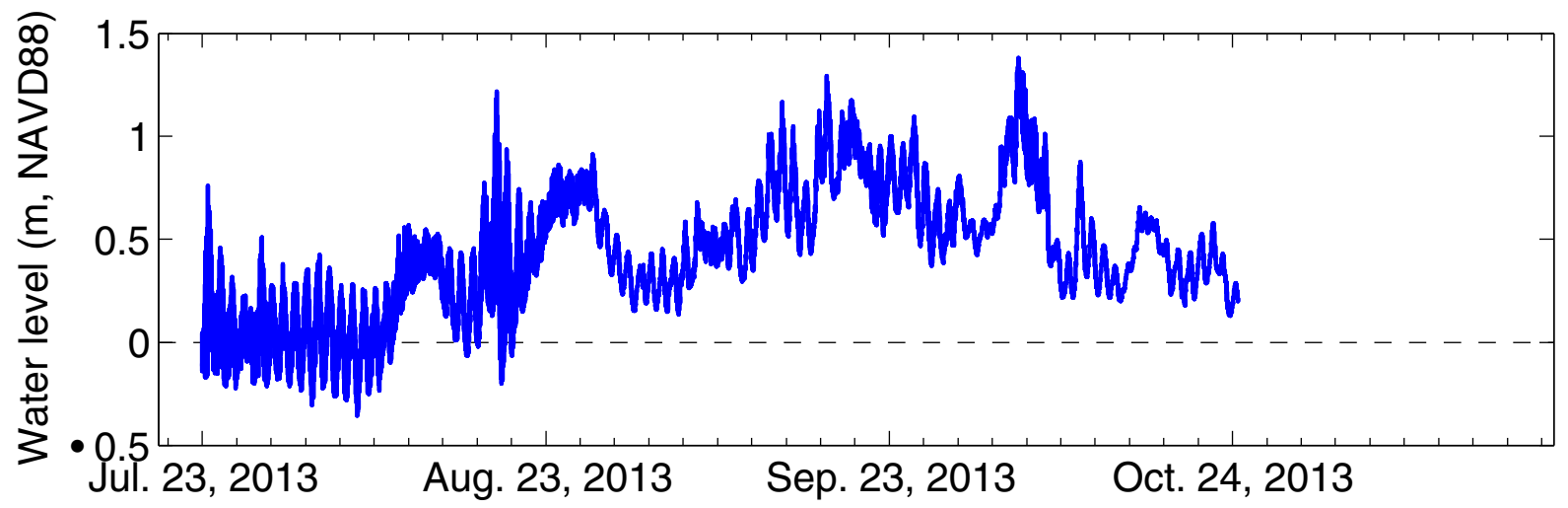

Figure 12. Water-level time series from an RBR Virtuoso D|wave pressure logger mounted in a buried well at site 968 on Dauphin Island, Alabama, in 2013. m, meters; NAVD88, North American Vertical Datum of 1988. 


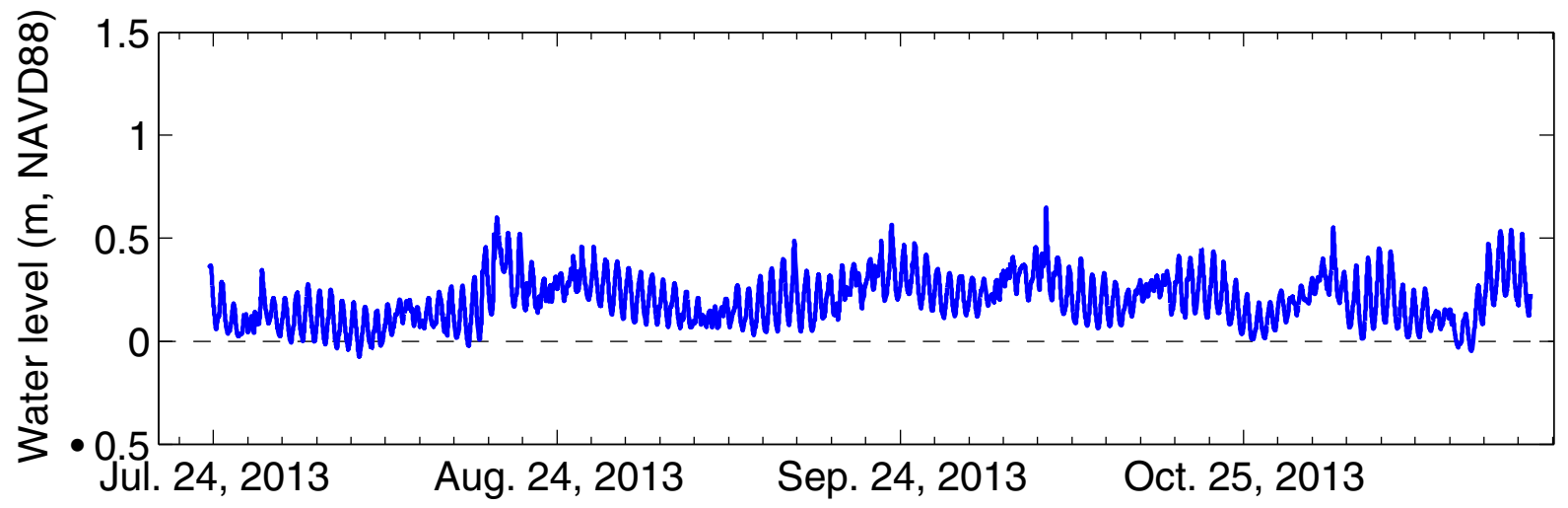

Figure 13. Water-level time series from an Onset Hobo U20 pressure logger mounted in a buried well at site 969 on Dauphin Island, Alabama, in 2013. m, meters; NAVD88, North American Vertical Datum of 1988.

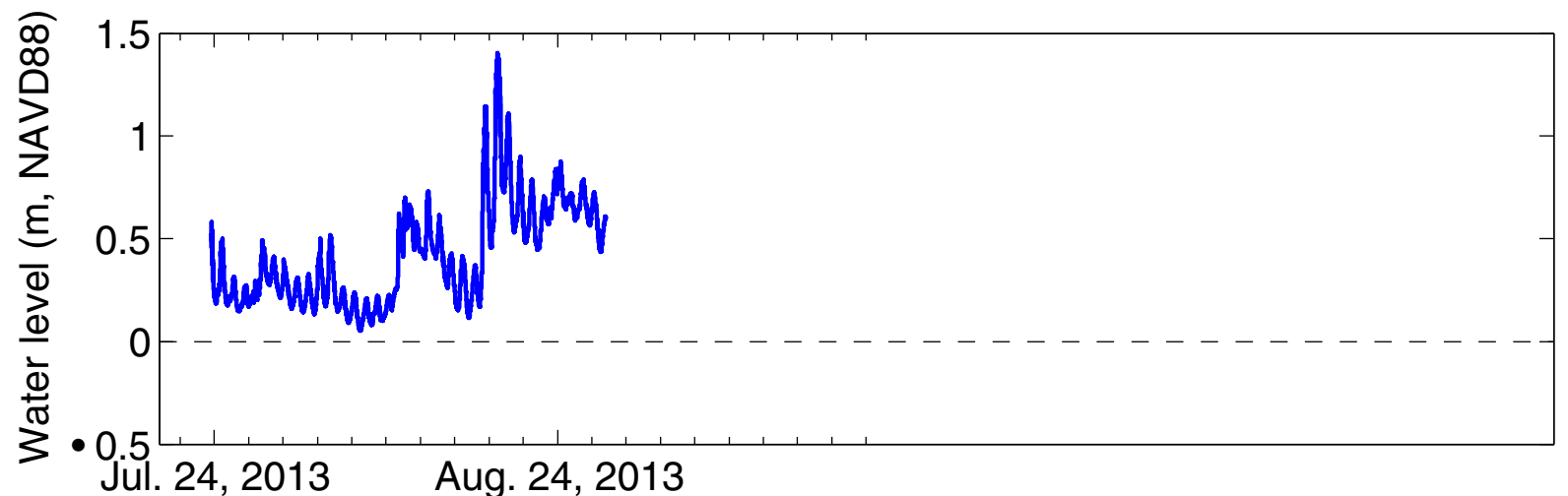

Figure 14. Water-level time series from an RBR DR1060 pressure logger mounted in a buried well at site 970 on Dauphin Island, Alabama, in 2013. m, meters; NAVD88, North American Vertical Datum of 1988. 


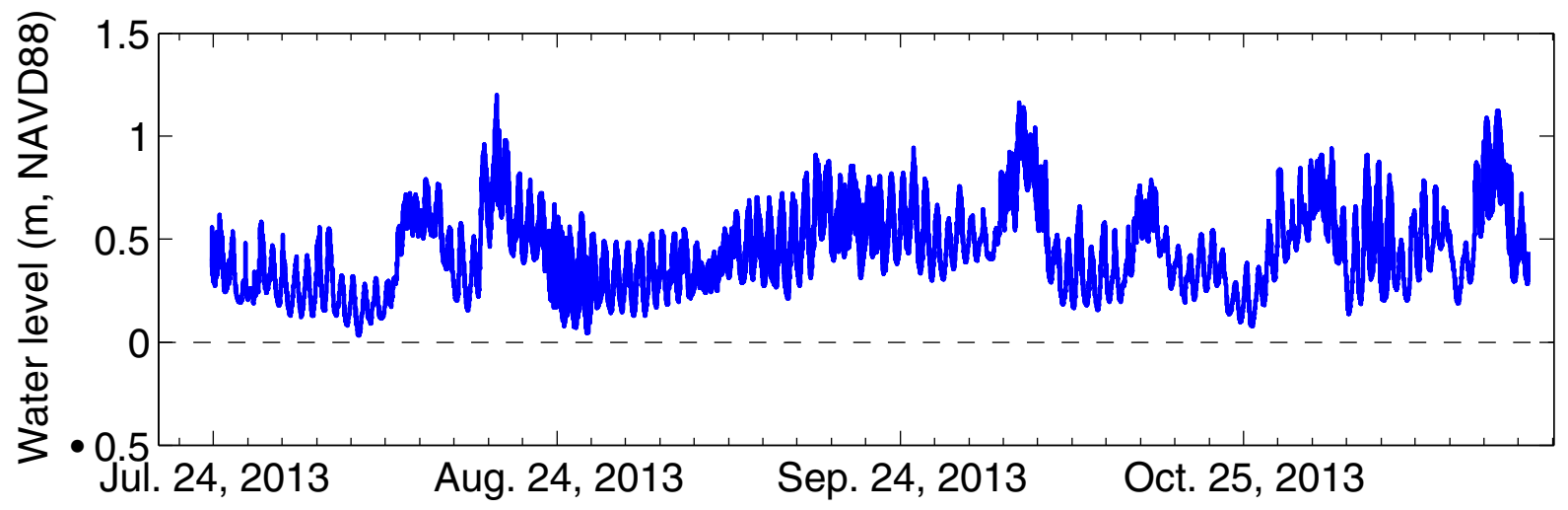

Figure 15. Water-level time series from an RBR DR1060 pressure logger mounted in a buried well at site 971 on Dauphin Island, Alabama, in 2013. m, meters; NAVD88, North American Vertical Datum of 1988.

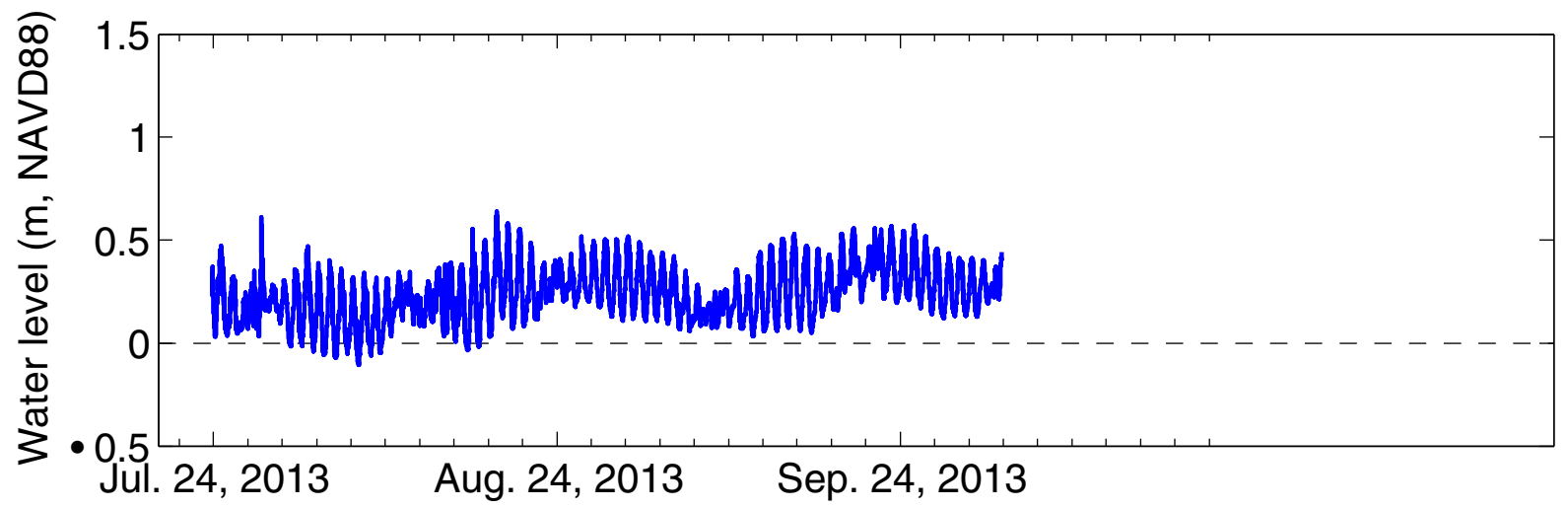

Figure 16. Water-level time series from an RBR DR1060 pressure logger mounted in a buried well at site 972 on Dauphin Island, Alabama, in 2013. m, meters; NAVD88, North American Vertical Datum of 1988. 


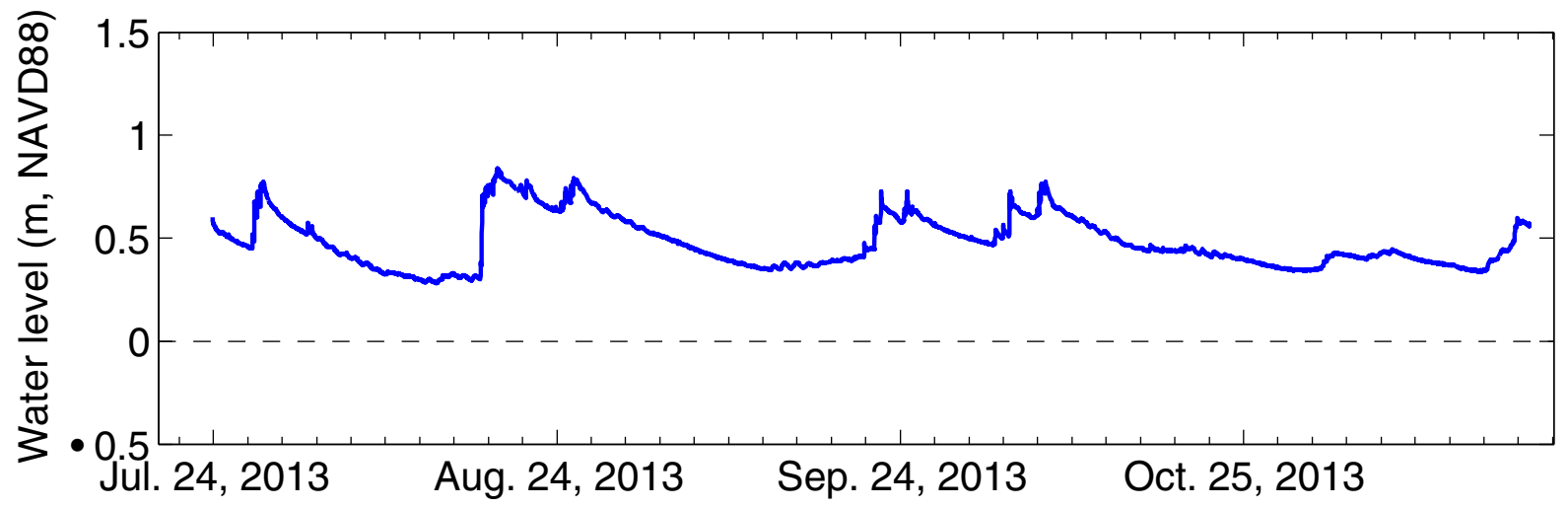

Figure 17. Water-level time series from an Onset Hobo U20 pressure logger mounted in a buried well at site 973 on Dauphin Island, Alabama, in 2013. m, meters; NAVD88, North American Vertical Datum of 1988.

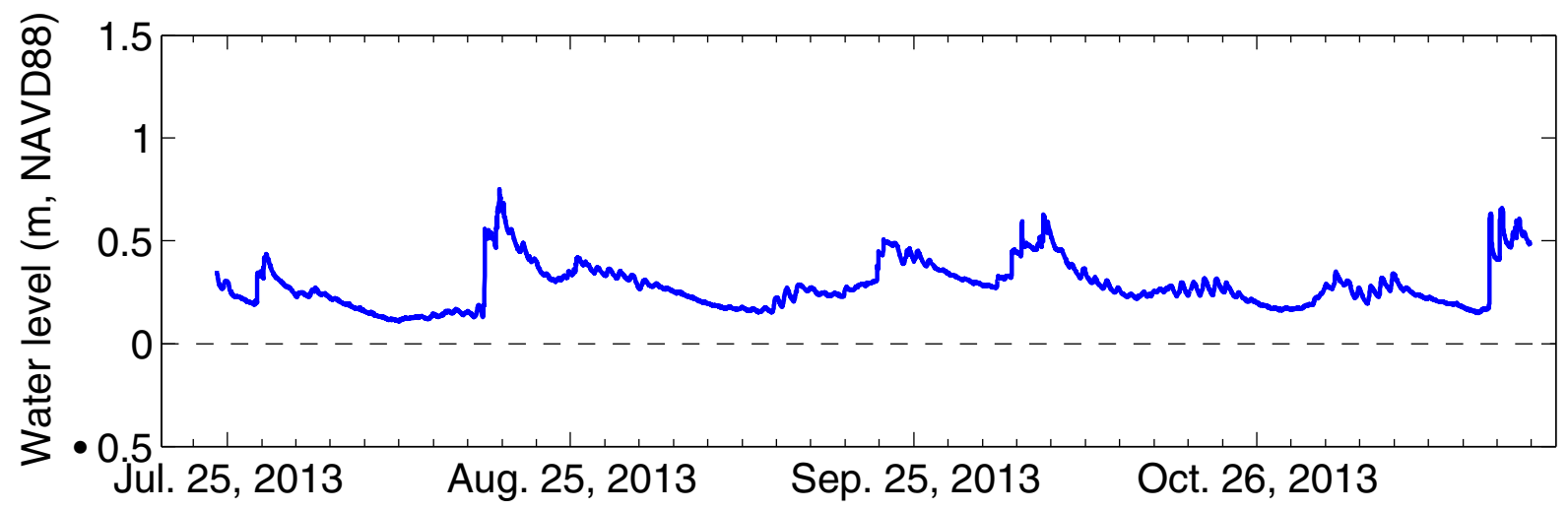

Figure 18. Water-level time series from an Onset Hobo U20 pressure logger mounted in a buried well at site 974 on Dauphin Island, Alabama, in 2013. m, meters; NAVD88, North American Vertical Datum of 1988. 


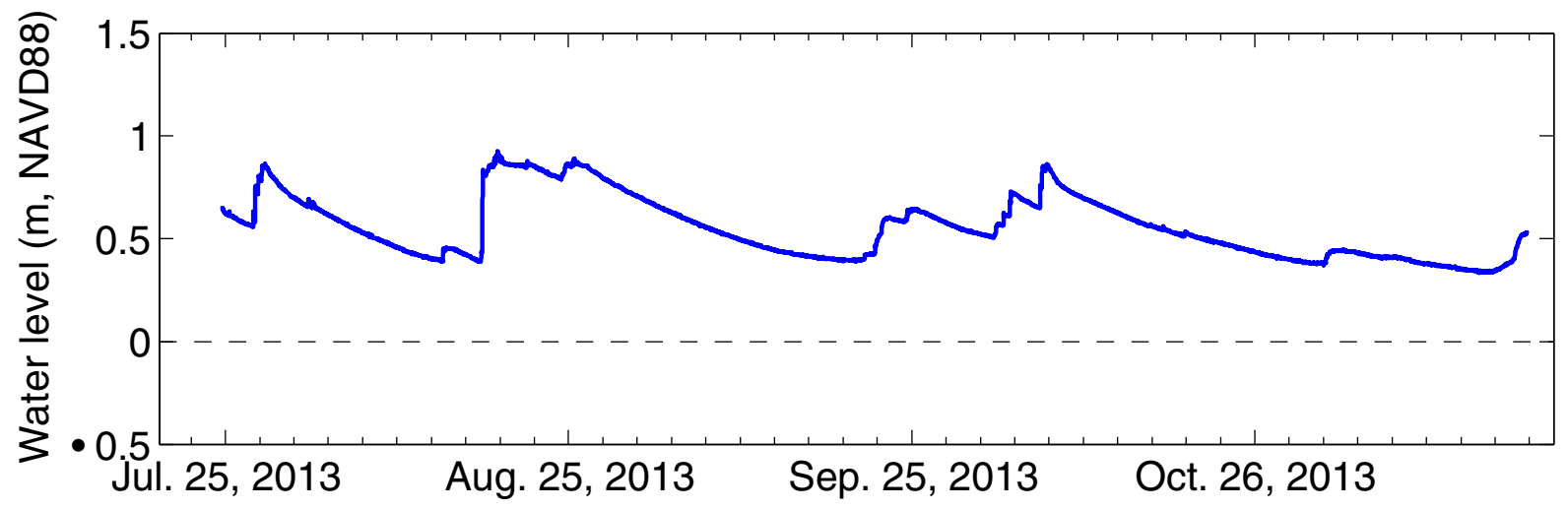

Figure 19. Water-level time series from an Onset Hobo U20 pressure logger mounted in a buried well at site 975 on Dauphin Island, Alabama, in 2013. m, meters; NAVD88, North American Vertical Datum of 1988.

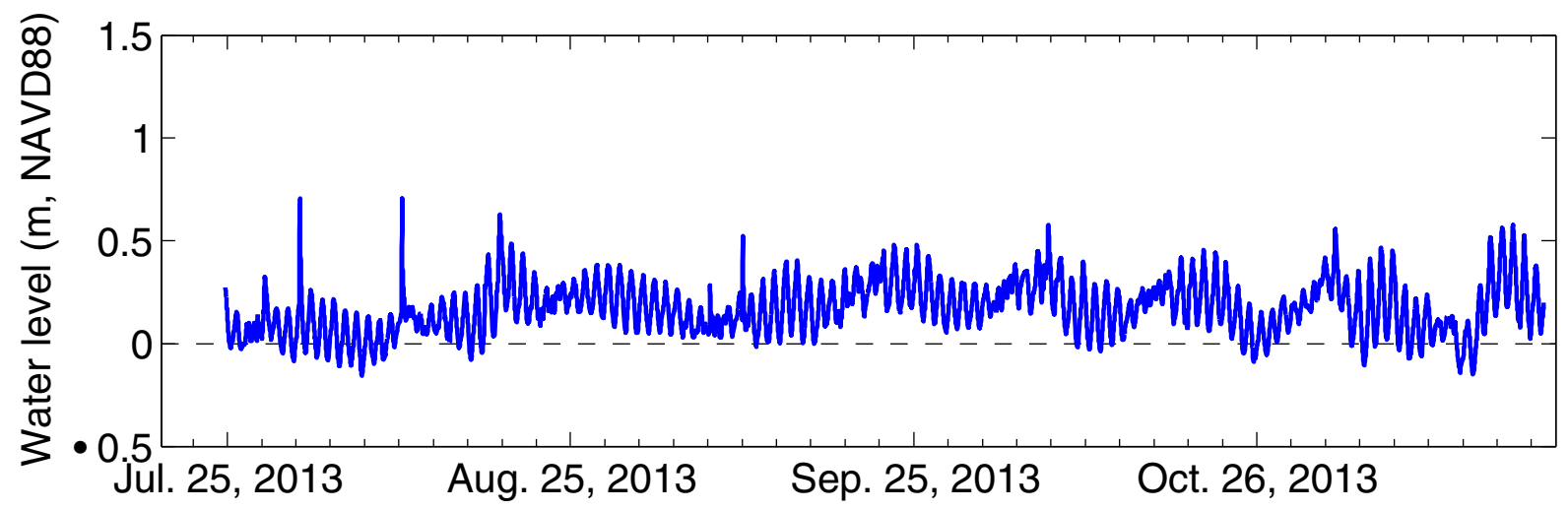

Figure 20. Water-level time series from an Onset Hobo U20 pressure logger mounted in a buried well at site 976 on Dauphin Island, Alabama, in 2013. m, meters; NAVD88, North American Vertical Datum of 1988. 


\section{Tables}

Table 1 Mooring log sensor, location, and deployment information.

[NAVD88, North American Vertical Datum of 1988; m, meter; N, north; W, west; UTC, Coordinated Universal Time; NA, not available]

\begin{tabular}{|c|c|c|c|c|c|c|c|c|c|}
\hline Sensor type & $\begin{array}{l}\text { Serial } \\
\text { Number }\end{array}$ & Site & $\begin{array}{c}\text { Sensor } \\
\text { elevation, in m } \\
\text { above NAVD88 }\end{array}$ & $\begin{array}{c}\text { Sensor } \\
\text { elevation } \\
\text { uncertainty, in } \\
\text { mabove } \\
\text { NAVD88 }\end{array}$ & $\begin{array}{c}\text { Distance } \\
\text { from cap to } \\
\text { sensor, in } \mathbf{m}\end{array}$ & Latitude N & Longitude W & $\begin{array}{c}\text { Time deployed, } \\
\text { UTC }\end{array}$ & Time recovered, UTC \\
\hline $\begin{array}{l}\text { Onset Hobo U20- } \\
001-04\end{array}$ & 10125471 & 965 & $\begin{array}{r}\text { atmospheric, } \\
\text { about } 4 \mathrm{~m}\end{array}$ & NA & NA & 30.25229 & 88.15276 & 7/22/13 15:15 & 11/20/13 21:29 \\
\hline RBR DR1060 & 24101 & 966 & -0.478 & 0.008 & 0.819 & 30.25289 & 88.15424 & 7/22/13 16:35 & 11/19/13 16:03 \\
\hline RBR DR1060 & 24032 & 967 & -0.873 & NA & 0.816 & 30.25055 & 88.19177 & 7/22/13 21:10 & Not recovered \\
\hline $\begin{array}{c}\text { RBR Virtuoso } \\
\text { D|wave }\end{array}$ & 55033 & 968 & -1.18 & 0.027 & 1.463 & 30.24834 & 88.19119 & $7 / 22 / 13$ 22:50 & 11/19/03 15:00 \\
\hline $\begin{array}{l}\text { Onset Hobo U20- } \\
\text { 001-01 }\end{array}$ & 10313354 & 969 & -0.269 & 0.014 & 0.678 & 30.25213 & 88.15872 & 7/23/13 16:08 & 11/19/13 22:00 \\
\hline RBR DR1060 & 24033 & 970 & -0.477 & 0.031 & 1.435 & 30.25019 & 88.15273 & 7/23/13 17:00 & 11/19/13 16:46 \\
\hline RBR DR1060 & 24099 & 971 & -0.490 & 0.014 & 1.43 & 30.24916 & 88.17568 & 7/23/13 20:15 & 11/19/13 17:02 \\
\hline RBR DR1060 & 24100 & 972 & -0.496 & 0.036 & 0.819 & 30.25232 & 88.17518 & 7/23/13 21:25 & 11/19/13 19:25 \\
\hline $\begin{array}{l}\text { Onset Hobo U20- } \\
\text { 001-04 }\end{array}$ & 10079949 & 973 & -0.501 & 0.029 & 1.24 & 30.251 & 88.17506 & 7/23/13 21:45 & 11/19/13 19:32 \\
\hline $\begin{array}{c}\text { Onset Hobo U20- } \\
\text { 001-01 }\end{array}$ & 10313355 & 974 & -0.763 & 0.022 & 1.305 & 30.24978 & 88.19102 & 7/24/13 0:58 & 11/19/13 17:35 \\
\hline $\begin{array}{l}\text { Onset Hobo U20- } \\
\text { 001-04 }\end{array}$ & 10079950 & 975 & -0.585 & 0.014 & 1.287 & 30.25164 & 88.15425 & 7/24/13 17:40 & 11/19/13 15:05 \\
\hline $\begin{array}{c}\text { Onset Hobo U20- } \\
\text { 001-01 }\end{array}$ & 10313353 & 976 & -0.237 & 0.008 & 0.683 & 30.25306 & 88.15217 & 7/24/13 18:18 & 11/20/13 22:00 \\
\hline
\end{tabular}


Table 2. National Oceanic and Atmospheric Administration benchmarks on Dauphin Island, Alabama. [Benchmarks are near the entrance of Fort Gaines on the eastern side of Dauphin Island. Benchmark BH1755 is in North American Datum of 1983 coordinate system and benchmark BH1755 is in World Geodetic System of 1984]

\begin{tabular}{cccc}
\hline & Latitude & Longitude & Ellipsoid \\
\hline BH1755 & 301458.82004 & 88433.67684 & -25.167 \\
BH1755 & 301458.83945 & 88433.70183 & -26.586 \\
\hline
\end{tabular}


Table 3. Instrumentation and data files for measuring water levels, atmospheric pressure, and temperature at Dauphin Island, Alabama. [UTC, Coordinated Universal Time; NA, not available]

\begin{tabular}{|c|c|c|c|c|c|}
\hline Sensor type & Serial Number & Site & Start of data record, UTC & End of data record, UTC & Data file name \\
\hline \multicolumn{6}{|c|}{ Atmospheric pressure and temperature measurements } \\
\hline Onset Hobo & 10125471 & 965 & 7/22/13 15:20:00 & 11/20/13 21:20:00 & 9651hwl-a.nc \\
\hline \multicolumn{6}{|c|}{ Water-level measurements } \\
\hline RBR DR1060 & 24101 & 966 & 7/22/13 16:35:00 & 11/18/13 8:46:28 & 9661rb-a.nc \\
\hline RBR DR1060 & 24032 & 967 & NA & NA & NA \\
\hline RBR D|wave & 55033 & 968 & 7/22/13 22:50:00 & 10/24/13 11:43:38 & 9681dw-a.nc \\
\hline Onset Hobo & 10313354 & 969 & 7/23/13 16:10:00 & 11/19/13 21:50:00 & 9691hwl-a.nc \\
\hline RBR DR1060 & 24033 & 970 & 7/23/13 17:00:04 & 8/28/13 8:27:52 & 9701rb-a.nc \\
\hline RBR DR1060 & 24099 & 971 & 7/23/13 20:25:08 & 11/19/13 17:01:56 & 9711rb-a.nc \\
\hline RBR DR1060 & 24100 & 972 & 7/23/13 21:25:04 & 10/03/13 4:10:12 & 9721rb-a.nc \\
\hline Onset Hobo & 10079949 & 973 & 7/23/13 22:10:00 & 11/19/13 19:30:00 & 9731hwl-a.nc \\
\hline Onset Hobo & 10313355 & 974 & 7/24/13 01:00:00 & 11/19/13 17:30:00 & 9741hwl-a.nc \\
\hline Onset Hobo & 10079950 & 975 & 7/24/13 17:50:00 & 11/19/13 15:00:00 & 9751hwl-a.nc \\
\hline Onset Hobo & 10313353 & 976 & 7/24/13 18:30:00 & 11/20/13 21:50:00 & 9761hwl-a.nc \\
\hline
\end{tabular}


ISSN 2331-1258 (online)

http://dx.doi.org/10.3133/ofr20141245 